\title{
Cordonnier Nonmicrobially-Defined Infection
}

National Cancer Institute

\section{Source}

National Cancer Institute. Cordonnier Nonmicrobially-Defined Infection. NCI Thesaurus.

Code C138292.

Any nonmicrobally-defined infection complications occurring in allogeneic stem cell transplant recipients. 